\title{
Behavior of Ten Chironja Clones at Three Sites. IV. Evaluation of Fresh and Processed Fruits ${ }^{1}$
}

\author{
Agripino Pérez-López, José R. Cruz Cay and José R. Benero²
}

\begin{abstract}
Fresh fruits of chironja clonal varieties were evaluated by a trained taste panel; five were rated as liked moderately, four as liked very much and one as liked slightly. These results confirm the acceptance of this new citrus fruit, consumed fresh. The appearance of the fresh fruit rated as follows: nine as liked moderately and one as liked very much. Large and small fresh fruits within each clonal variety rated equally for appearance and flavor. Clonal varieties $2-4$ and 3-8 had the thickest and thinnest peels, respectively; there was no difference in the peel thickness in the other varieties. Rinds of the 10 varieties processed in heavy syrup were acceptable or very acceptable. The average fruit weight and juice yield varied among varieties.

The frozen and pasteurized chironja juice of all the clonal varieties was rated as unacceptable or slightly unacceptable by the taste panel. These results show that chironja juice is not suitable for canning; it must be consumed fresh.
\end{abstract}

\section{INTRODUCTION}

The method for canning chironja sections developed by Benero and Carlo (2) and that of Cruz-Cay (3) for processing this fruit suggested that screening should be done to evaluate ten chironja clones under research at our three substations.

\section{MATERIALS AND METHODS}

The procedure for the establishment and management practices of the chironja orchard has been described elsewhere (6).

When the trees started bearing heavily (7 years) fruits were collected at a height of $2 \mathrm{~m}$ around the canopy of each tree. Each variety was harvested separately. Fruits more than 50\% yellow were sampled and evaluated.

\section{FRESH FRUIT}

The fruits were heterogeneous as to size, color and shape. The samples were washed and divided into large and small fruits. Fruits in each group were evaluated separately.

A nine-point hedonic scale ranging from 1 (dislike extremely) to 9 (like extremely) was used for sensory evaluation (7).

Large fruits had a central axis of at least $9 \mathrm{~cm}$ or longer and small ones

${ }^{1}$ Manuscript submitted to Editorial Board December 3, 1979.

${ }^{2}$ Horticulturist, Assistant Food Technologist, and Associate Chemist, respectively, Agricultural Experiment Station, College of Agricultural Sciences, Mayagüez Campus, University of Puerto Rico, Mayagüez and Río Piedras, P.R. 
had a central axis of no more than $8 \mathrm{~cm}$. Fruits were cut lengthwise into four sections, one of which was presented each taster for flavor evaluation.

A composite sample of large and small fruits was presented to the panel for appearance evaluation.

\section{PROCESSED FRUITS AND JUICE}

The ten varieties were evaluated as chironja rind in heavy syrup. Fruits for this purpose were lye-peeled by being dipped in a boiling $10 \%$ sodium hydroxide solution for 20 seconds, then washed in a rotary vegetable washing machine, and cleaned by hand with nylon brushes. The peeled chironjas were quartered and the rind removed. The thickness of the rind was measured at the blossom end, middle and at the stem end. The rind was then cooked in boiling water for $3 \mathrm{~min}$ to soften the tissues, then

TABLE 1.-Sensory evaluation of large fruits and percentage of small fruits of samples of 10 clonal varieties of chironja

\begin{tabular}{lccc}
\hline Clone & Flavor $^{1}$ & Appearance & Small fruits \\
\hline & & & $\%$ \\
$2-3$ & 7.3 & 6.8 & 63 \\
$3-6$ & 7.7 & 6.6 & 42 \\
$2-4$ & 6.3 & 7.4 & 33 \\
$4-11$ & 6.9 & 6.7 & 52 \\
$3-8$ & 7.8 & 7.9 & 26 \\
$3-4$ & 7.1 & 7.1 & 30 \\
$6-12$ & 7.6 & 6.9 & 54 \\
$2-7$ & 7.4 & 7.4 & 42 \\
$5-7$ & 7.5 & 6.7 & 39 \\
$3-3$ & 6.7 & 7.3 & 30 \\
\hline
\end{tabular}

${ }^{1}$ Evaluated with a hedonic scale (8), 1 (dislike extremely) to 9 (like extremely).

soaked in tap water for about $15 \mathrm{~h}$, the water being changed two or three times during this period.

Fruit bars were prepared by grinding the rinds in a meat and vegetable grinding machine with a $1 / 8$-inch hole die, then mixed with 1.17 times their weight of sugar; the pH was adjusted to 4.0 with citric acid. The resulting mixture was then cooked to $70^{\circ}$ Brix. The fruit bars were formed in frames 9 inches by $3 \frac{3 / 4}{4}$ inches and dried in a tray dryer, warm air drying them until a thin sugary crust was formed.

For the preparation of the rinds in heavy syrup, the following procedure was followed: the rinds were mixed with 3 times their weight of a $30^{\circ}$ Brix syrup adjusted to $\mathrm{pH} 4.0$ with citric acid. Then $.07 \%$ of cinnamon sticks were added. The mixture was then cooked until the syrup reached $55^{\circ}$ Brix, canned in enameled tin cans $211 \times 400$, and processed for 25 min in boiling water. 
The fruit bars and the rinds were submitted to sensory evaluation to determine their acceptability level following the simplified method (5). Each sample was evaluated on a specific scale of five points where +2 indicated "very acceptable"; + 1 "acceptable"; 0 "questionable"; -1 "slightly unacceptable"; and -2 "not acceptable."

A sample of fruits of each of the 10 clonal varieties was weighed, and the number of fruits in each sample was counted. The juice was extracted with a reamer, and weighed. The average fruit weight, the amount of juice yielded by each clone sample, and the amount of juice yielded by the average size fruit of each clone was determined. Half of the extracted juice of each clone was frozen; the rest was pasteurized at $88^{\circ} \mathrm{C}$, canned and stored at $7^{\circ} \mathrm{C}$ (4). Frozen and pasteurized juices were submitted to sensory evaluation by a tasting panel using the Kramer and Ditman

TABLE 2.-Peel percentage thickness and panel score of the 10 chironja clonal varieties

\begin{tabular}{lccc}
\hline \multirow{2}{*}{ Clone } & \multicolumn{2}{c}{ Peel } & Taste panel score $^{\mathrm{t}}$ \\
\cline { 2 - 3 } & Percentage & Thickness & \\
\hline & & Cm & 1.5 \\
$3-3$ & 22 & 0.51 & 1.1 \\
$2-6$ & 24 & 0.51 & 0.9 \\
$4-11$ & 22 & 0.64 & 0.9 \\
$3-8$ & 23 & 0.43 & 1.0 \\
$3-4$ & 23 & 0.33 & 1.3 \\
$6-12$ & 25 & 0.51 & 0.7 \\
$2-7$ & 25 & 0.43 & 1.1 \\
$5-7$ & 28 & 0.43 & 1.5 \\
$3-3$ & 23 & 0.43 & 0.6 \\
\hline
\end{tabular}

${ }^{1}$ The taste panel score applies to both fruit bars and rinds in heavy syrup evaluated with a 5 -point scale (5), ( -2 (not acceptable) to +2 (very acceptable).

simplified variable taste panel method (5). Chemical determinations of Brix, $\mathrm{pH}$, acidity, vitamin $\mathrm{C}$, reducing and total sugars, and total solids were performed on both frozen and pasteurized juices by the methods described in the O.A.A.C. (1).

\section{RESULTS AND DISCUSSIONS}

Table 1 shows that in relation to flavor, variety $2-4$. was classified as liked slightly. This is probably due to the fact that it is a very large fruit with the lowest Brix, sugars and total solids.

Varieties 2-3, 4-11, 3-4, 2-7 and 3-3 were rated as liked moderately, while varieties $3-6,3-8,5-7$ and $6-12$ were rated as liked very much. These results confirm those of Moscoso (6), who reported the high acceptability of the chironja. 
In relation to the appearance, table 1 shows that clone $3-8$ was rated as liked very much, while the rest of the varieties were rated as liked moderately. These results again show the acceptability of the chironja as a fresh fruit.

Table 1 also shows the percentage of small fruits. There is a great variation in the percentage of small fruits among the varieties.

Large and small fruits within varieties did not differ in flavor and appearance. For this reason the data of the large fruits are presented.

Table 2 shows the percentage and thickenss of the peel and the taste test score of the fruit bars and rinds in heavy syrup. The peel thickness of variety $2-4$ was $.64 \mathrm{~cm}$., twice as thick as variety $3-8$, which was .33 $\mathrm{cm}$.; the other fruits ranged from .40 to $.50 \mathrm{~cm}$.

TABLE 3.-Average fruit and juice weight, percentage of juice yielded per average size fruit, and taste panel score of frozen and pasteurized juice of the 10 chironja clonal varieties

\begin{tabular}{|c|c|c|c|c|c|}
\hline \multirow{2}{*}{ Clone } & \multicolumn{2}{|c|}{ Mean weight } & \multirow{2}{*}{ Juice yield } & \multicolumn{2}{|c|}{ Taste panel juice score ${ }^{1}$} \\
\hline & Fruit & Juice & & Frozen & Pasteurized \\
\hline & $g$ & $g$ & $\%$ & & \\
\hline $3-8$ & 545 & 213 & 39 & -0.3 & -1.2 \\
\hline $2-4$ & 545 & 213 & 39 & -0.1 & -1.5 \\
\hline $2-7$ & 499 & 200 & 40 & -0.3 & -1.2 \\
\hline $3-3$ & 499 & 195 & 39 & -0.2 & -0.6 \\
\hline $3-6$ & 454 & 195 & 43 & -0.3 & -1.5 \\
\hline $4-11$ & 454 & 191 & 42 & -0.2 & -1.2 \\
\hline $6-12$ & 454 & 173 & 38 & -0.1 & -0.7 \\
\hline $3-4$ & 454 & 168 & 37 & -0.2 & -1.2 \\
\hline $5-7$ & 454 & 168 & 37 & -0.2 & -0.9 \\
\hline $2-3$ & 409 & 176 & 43 & -0.8 & -1.5 \\
\hline
\end{tabular}

${ }^{1}$ Juice evaluated with a 5 -point scale (5), ( -2 (not acceptable) to +2 (very acceptable).

The fruit bars and rind in heavy syrup for all the varieties were rated acceptable or very acceptable. Clones 3-3 and 6-12 had a score of 0.6 and 0.7 respectively, which is fairly low as compared to scores of other varieties. The lower rating is probably due to process failures instead of processing characteristics of the varieties. The reasons given by the tasters for the low rating were that the rinds in heavy syrup were too hard, bitter, and that there was too much peel left. Improvement in the process may improve the quality of the product.

Table 3 shows the mean fruit and juice weight, percentage of juice, and the score for frozen and pasteurized juice of the 10 chironja clonal varieites.

Clones 2-4 and 3-8 produced the biggest fruits (545 g), while clone 2- 
3 produced the smallest ( $409 \mathrm{~g}$ ). Clone $2-3$ and $3-6$ had the highest juice content (43\%). The large fruits, as expected, yielded more juice than the small ones, with the exception of clone $2-3$, which produced more juice than clones 5-7, 3-4 and 6-12, which were heavier than 2-3. Single strength frozen and pasteurized juices of all 10 clones were unacceptable or slightly unacceptable to the panel.

Table 4 shows the composition of frozen and pasteurized juices.

TABLE 4.- ${ }^{\circ}$ Brix, $p H$, acidity, vitamin $C$, reducing sugars, total solids and total sugars of frozen and pasteurized juice of 10 chironja clonal varieties

\begin{tabular}{lccccccc}
\hline Clone & Brix & $\mathrm{pH}$ & Acidity & Vitamin C & $\begin{array}{c}\text { Reducing } \\
\text { sugars }\end{array}$ & Total sugars Total solids \\
\hline & & \multicolumn{7}{c}{ Frozen } \\
2-3 & 11 & 4.1 & 0.44 & 9.5 & 3.6 & 9.2 & $\%$ \\
$3-6$ & 11 & 4.1 & 0.48 & 9.7 & 3.5 & 9.8 & 7.2 \\
$2-4$ & - & - & - & - & - & - & - \\
$4-11$ & 10 & 4.2 & 0.37 & 9.7 & 3.5 & 9.8 & 6.9 \\
$3-8$ & 11 & 4.2 & 0.41 & 9.5 & 4.1 & 9.5 & 6.9 \\
$3-4$ & 10 & 4.2 & 0.43 & 10.1 & 3.2 & 9.6 & 6.5 \\
$6-12$ & 11 & 4.2 & 0.41 & 9.5 & 3.9 & 9.2 & 6.8 \\
$2-7$ & 10 & 4.3 & 0.45 & 9.7 & 3.6 & 8.8 & 6.8 \\
$5-7$ & 10 & 4.3 & 0.43 & 9.5 & 3.6 & 9.2 & 6.6 \\
$3-3$ & 10 & 4.3 & 0.40 & 9.5 & 3.8 & 9.1 & 6.5 \\
& & & Pasteurized & & & \\
$2-3$ & 10 & 4.0 & 0.46 & 9.8 & 5.2 & 9.5 & 7.8 \\
$3-6$ & 10 & 4.3 & 0.38 & 10.1 & 3.7 & 8.9 & 6.6 \\
$2-4$ & 9 & 4.3 & 0.38 & 9.8 & 3.5 & 8.0 & 5.9 \\
$4-11$ & 11 & 4.1 & 0.48 & 10.1 & 3.7 & 9.0 & 7.0 \\
$3-8$ & 10 & 4.3 & 0.42 & 9.5 & 4.2 & 9.3 & 6.8 \\
$3-4$ & 10 & 4.3 & 0.42 & 10.1 & 3.5 & 8.9 & 6.9 \\
$6-12$ & 10 & 4.3 & 0.43 & 10.1 & 4.0 & 9.5 & 6.9 \\
$2-7$ & 10 & 4.2 & 0.44 & 10.1 & 3.6 & 8.9 & 6.5 \\
$5-7$ & 10 & 4.3 & 0.40 & 8.8 & 4.0 & 8.9 & 6.8 \\
$3-3$ & 10 & 4.3 & 0.37 & 9.5 & 4.1 & 9.3 & 6.7 \\
\hline
\end{tabular}

\section{RESUMEN}

Frutas frescas y en conserva de diez variedades clonales de chironja se evaluaron con los siguientes resultados:

En relación al sabor de la fruta fresca, a los catadores les gustaron moderadamente las de cinco clones, mucho las de cuatro, y ligeramente las de uno. Con relación a la apariencia de la fruta fresca, nueve gustaron moderadamente y una mucho.

Las frutas grandes y pequeñas tuvieron la misma aceptación con respecto a la apariencia y el sabor. Por esta razón solamente se discuten los datos referentes a las frutas grandes. 
Las frutas del clon 2-4 tienen la cáscara más gruesa y las del 3-8 la más fina. Entre las frutas de los otros clones no hubo diferencia. La compota en almíbar espeso de la cáscara de los diez clones fue aceptable y muy aceptable.

La cantidad de jugo de las frutas de cada clon varió según su tamaño. Tanto el jugo congelado como el pasteurizado fueron inaceptables para los catadores, lo cual indica que el jugo de estos clones debe consumirse en fresco.

\section{LITERATURE CITED}

1. Assoc. Offi. Agric. Chem., 1970. Official methods of analysis, Washington, D.C.

2. Benero, J. R. and Carlo, L. A., 1965. Canning chironja sections, J. Agri. Univ. P.R. 49 (3): 388.

3. Cruz-Cay, J. R., 1972. Processing of chironja, J. Agri. Univ. P. R. 65 (1): 183-4.

4. Díaz, N., 1976. Effect of storage at $45^{\circ} \mathrm{F}\left(7^{\circ} \mathrm{C}\right)$ on keeping quality of five chironja clones, J. Agri. Univ. P.R. 60 (3): 348-68.

5. Kramer, A. and Ditman, L. P., 1956. A simplified variable taste panel method for detecting flavor changes in vegetables treated with pesticides, Food Technol. 10 (3): $155-9$.

6. Pérez-López, A., Sotomayor-Ríos, A., and Torres-Rivera, S., 1979. Studies on characters of chironja seedling trees, J. Agri. Univ. P.R. 64 (2): 232-5.

7. Peryam, D. R. and Pilgrim, F. J., 1957, Hedonic scale method of measuring food preferences, Inst. Food Technol., Chicago, Ill. 